Two Strings to One Bow?

Article 47 of the EU Charter of Fundamental Rights in the EU Competition Case Law: Between Procedural and Substantive Fairness ${ }^{*}$

\title{
Giulia Gentile**
}

\begin{abstract}
In recent years, the EU competition framework has been under strain because of the increasing market interconnectivity. Criticisms have increased regarding the EU competition enforcement model. In response, institutional debate and measures have focused on the enhancement of fairness in this area of EU law. Following the entry into force of the Lisbon Treaty, another source of "fairness" in the enforcement of EU competition law is the EU Charter of Fundamental Rights.

Article 47 of the EU Charter is the most invoked provision in the context of EU competition litigation. Considered to reaffirm the EU general principle of effective judicial protection, this article constitutionalises the right to an effective remedy and to a fair trial. Although the existing literature has highlighted the overall influence of fundamental rights in the enforcement of competition law, the contribution of Article 47 of the Charter to the enhancement of fairness in EU competition policies, as interpreted by the Court of Justice of the European Union, remains underexplored.

The current article aims to fill this gap in the literature by offering a threefold input. First, the article situates the discussion on fairness in EU competition law in the broader philosophical debate regarding various conception(s) of fairness. Second, the article analyses the case law of the EU Court of Justice on Article 47 of the EU Charter in EU competition litigation. Finally, the article discusses what kind of "fairness" Article 47 strengthens in the area of EU competition law enforcement.
\end{abstract}

\footnotetext{
* Date of reception: 3 June 2020. Data of acceptance: 16 August 2020. DOI: https://doi.org/10.34632/mclawreview.2020.9525.

** Visiting lecturer and PhD candidate at the Dickson Poon School of Law, King's College London, giulia.gentile@kcl.ac.uk. I would like to thank the anonymous reviewers for their useful comments.
} 
KEYWORDS: EU Charter of Fundamental Rights, Article 47 of the EU Charter, EU competition law, European Court of Justice, fairness

\section{Introduction}

Since the 1980s, the growing market interconnectivity has posed new challenges to the effective enforcement of EU competition law. ${ }^{1}$ The existing legal framework has been considered only relatively successful to address these issues. ${ }^{2}$ As a result, institutional debate ${ }^{3}$ has focused on the enhancement of fairness in the enforcement of EU competition rules. For instance, Commissioner Vestager has consistently cited fairness as one of the principles that should guide the application of the EU competition framework. ${ }^{4}$ The attention to fairness in the competition sector should not, however, come as a surprise. Indeed, fairness is all around EU competition law: Articles 101 and 102 TFEU refer in various ways to the concept of "fairness".

Although the precise meaning of fairness in EU competition law is controversial, in recent years, multiple initiatives have attempted to enhance fairness in that area of law. For example, in 2012, extensive discussions on procedural fairness in the competition field were initiated by, among others, the Organisation for Economic Co-operation and Development. ${ }^{5}$ Fairness considerations also led to the adoption of soft law instruments ${ }^{6}$ such as the Commission's notice on best practices for proceedings under Articles 101 and 102 TFEU. This measure seeks to increase the understanding of the Commission's investigation processes and "ensure a high degree

\footnotetext{
${ }^{1}$ Felipe González and Stanley Hoffmann, "European Union and globalization", Foreign Policy, no. 115 (1999): 28.

${ }^{2}$ Ian Forrester recalls a speech given in 1982 concerning a plea for reform of the EC competition system. Ian Forrester, "Modernization of EC competition law", Fordham International Law Journal 23, no. 4 (2000): 1028.

${ }^{3}$ Johannes Laitenberger "Fairness in EU competition law enforcement", British Chambers of Commerce EU \& Belgium, 20 June 2018, https://bit.ly/335se2Q.

${ }^{4}$ E.g. Margarethe Vestager, "Fairness and competition", Brussels GCLC Annual Conference, 25 January 2018, https://bit.ly/3i4sxBc.

${ }^{5}$ OECD Competition Committee, "Procedural fairness and transparency", 2012, https://bit. ly/3bsBcuY; WTO, "Competition policy, trade and the global economy: Existing WTO elements, commitments in regional trade agreements, current challenges and issues for reflection”, 31 October 2018, https://bit.ly/3h3rZue.

${ }^{6}$ European Parliament and Council Directive 2009/72/EC Concerning Common Rules for the Internal Market in Electricity and Repealing Directive 2003/54/EC, 13 July 2009.
} 
of transparency and predictability in the process". ${ }^{7}$ Further, academics have reflected on the fairness of fines imposed on companies, ${ }^{8}$ whereas the public debate has highlighted the fairness considerations prompting recent investigations against big tech giants. ${ }^{9}$

Another source of "fairness" in the field of EU competition law is the EU Charter of Fundamental Rights. ${ }^{10}$ The Charter offers the first official catalogue of fundamental rights protected in the $\mathrm{EU}$ and binds the $\mathrm{EU}$ and the Member States when they implement EU law. ${ }^{11}$ Charter rights are thus an expression of constitutionalised fairness in the EU legal order.

It is well established that legal orders where basic liberties and rights are not envisaged would not be characterised by justice and, therefore, fairness. By protecting interests considered "essential" in a society, fundamental rights are a form of legal entitlement and offer individual guarantees against unjustified interferences reducing the enjoyment of that entitlement. Additionally, the EU legal order is based on fairness considerations. EU Treaty freedoms provide individuals in the EU with "essential rights". ${ }^{12}$ Moreover, through the case law of the Court of Justice, ${ }^{13}$ the EU order has been enriched with fundamental rights in the form of the general principles of EU law. The entry into force of the EU Charter in 2009 evidently marked a further step in the advancement of fairness aspirations in the EU legal system. EU fundamental rights have, in fact, acquired a more prescriptive and defined content thanks to the Charter. The judicial application of the Charter in the context of EU competition litigation contributes to ensuring "fairness" in that sector as well.

\footnotetext{
${ }^{7}$ Commission notice on best practices for the conduct of proceedings concerning Articles 101 and 102 TFEU.

${ }^{8}$ Arianna Andreangeli, "Competition law and fundamental rights", Journal of European Competition Law \& Practice 8, no. 8 (2017): 524.

${ }^{9}$ E.g. "Apple can’t ignore antitrust outcry. Here's a game plan", Bloomberg, 22 June 2020, https:// bloom.bg/3hY0bZv.

${ }^{10}$ See Article 6 TEU.

${ }^{11}$ Article 51 of the EU Charter.

${ }^{12}$ Nik J. de Boer, "Fundamental rights and the EU internal market: Just how fundamental are the EU treaty freedoms? A normative enquiry based on John Rawls' political philosophy", Utrecht Law Review 9, no. 1 (2013): 149.

${ }^{13}$ Hereafter, "CJEU", which indicates, collectively, the European Court of Justice ("ECJ") and the General Court "GC".
} 
Article 47 of the EU Charter ${ }^{14}$ ("Article 47 Charter" or "Article 47"), protecting the right to an effective remedy and a fair trial, is the most cited Charter right in the EU competition litigation. This provision has become the primus inter pares among the Charter rights in the competition field. The question thus arises: What is the contribution of Article 47 in enhancing fairness in the enforcement of EU competition law?

The current article addresses this question and is structured as follows. First, it conducts a literature review of the conceptions of "fairness" in the field of EU competition law, also in the light of the broader legalphilosophical debate on "fairness". The article then moves on to analysing the CJEU case law on Article 47 Charter as applied in EU competition litigation. Finally, the article discusses what kind of "fairness" Article 47 strengthens in the area of EU competition law enforcement.

\section{Notions of fairness: A conceptual discussion}

The ever-evolving notion of fairness is omnipresent in legal theory and most fields of law. Two types of notion of fairness may be traced: substantive and procedural. As will be discussed below, substantive and procedural fairness acquire different nuances, in both literature and various areas of law.

To begin with, substantive fairness does not have a univocal definition. As its roots, legal philosophers have identified the ideals of justice and equality. Because of the variability of just outcomes in different legal systems and policy sectors, there is no unique meaning that can be attributed to substantive fairness. However, what joins the different conceptions of this type of fairness is that they all aspire to achieve policy objectives acceptable to and benefitting the community of reference.

Rawls developed one of the most debated notions of substantive fairness. ${ }^{15}$ In Rawls' reconstruction, fairness is intrinsically linked with justice from a distributional point of view. Namely, fairness requires equitable distribution of gain. Other theorists have conceptualised substantive fairness from an efficiency angle. Fairness as efficiency applies mainly in negotiations, where the risks will be allocated to the party who can bear

\footnotetext{
${ }^{14}$ Article 47 appears in 122 judgments delivered in the field of competition litigation from the $1^{\text {st }}$ of December 2010 until 30 April 2020. See https://bit.ly/2GynSKa. In the same timeframe, Article 41 of the EU Charter figures in 82 cases. See https://bit.ly/3btHcDP.

${ }^{15}$ John Rawls, A Theory of Justice (Harvard: Harvard College Press, 2005).
} 
them at the least cost. ${ }^{16}$ This latter conception of fairness takes into account the situation of individuals in theorising the distribution of rights and obligations.

Substantive fairness aspirations are enshrined in various areas of law, such as employment, ${ }^{17}$ contract, ${ }^{18}$ and administrative law. In these fields, fairness is both an objective and a principle, used to recalibrate imbalanced situations such as those between an employer and the employee. In UK administrative law, substantive justice (or fairness) is a legal ground for scrutinising administrative decisions. Such standards include the principle of equality ${ }^{19}$ and ensure the balancing of individual rights against the administration. ${ }^{20}$

In its procedural meaning, instead, fairness regulates the participatory rights of entities involved in decision-making procedures. From this angle, the focus of fairness is not the outcome of decisions, but rather the way in which agreement is reached. There is also the belief that procedural fairness leads to "better" decision-making, in the sense that final agreements are more democratic and representative. Procedural fairness considerations may apply in relation to any sort of system or procedure, legislative or judicial.

The implications of procedural fairness have been widely studied. For instance, Tyler ${ }^{21}$ observed that procedural fairness significantly contributes to the acceptance of the regulatory model in a legal order. Furthermore, Sustein ${ }^{22}$ has identified two notions of procedural fairness: "the first, embodied in the rule of law ideal, calls for clear rules, laid down in advance and susceptible to mechanical application in individual cases.

\footnotetext{
${ }^{16}$ Frank H. Buckley, "Three theories of substantive fairness", Hofstra Law Review 19, no. 1 (1990): 35.

${ }^{17}$ Ioannis Lianos, Nicola Countouris and Valerio de Stefano, "Re-thinking the competition law/ labour law interaction: Promoting a fairer labour market", European Labour Law Journal 10, no. 3 (2019): 291-333.

${ }^{18}$ Buckley, "Three theories".

${ }^{19}$ David J. Mullan, "Natural justice and fairness - Substantive as well as procedural standards for the review of administrative decision-making?", Revue de Droit de McGill 27, no. 2 (1981): 287.

${ }^{20}$ Kaplow and Shavell similarly argue that supporting any notion of fairness will result in lowering the overall wellbeing of a community. Louis Kaplow and Steven Shavell, "The Conflict between notions of fairness and the pareto principle", American Law and Economics Review 1, no. 1/2 (2000).

${ }^{21}$ Tom R. Tyler, "Procedural justice, legitimacy, and the effective rule of law", Crime and Justice 30 (2003): 283-327.

${ }^{22}$ Cass R Sunstein, "Two conceptions of procedural fairness", Social Research: An International Quarterly 73, no. 2 (2006): 619.
} 
The second calls for a high degree of individuation, on the theory that fairness requires particularized consideration of the whole person". These two conceptions are not sharply different but are part of a continuum.

To conclude, procedural and substantive fairness are complementary: for a system to be fair, all individuals should have the same opportunities to equitable rights and gains and should benefit, in principle, from the same participatory guarantees in decision-making processes. Procedural fairness reinforces substantive fairness and vice-versa.

As discussed in the following section, significant academic debate surrounds the role of both substantive and procedural fairness in the EU competition sector.

\subsection{Fairness in EU competition law}

In the latest speeches of Competition Commissioner Vestager, fairness is omnipresent. ${ }^{23}$ For example, in 2016, she ${ }^{24}$ stressed that "competition enforcement also sends a message of fairness. That public authorities are here to defend the interests of individuals, not just to take care of big corporations". ${ }^{25}$ The recent focus on the enhancement of fairness in the EU competition sector emerged following criticisms practitioners ${ }^{26}$ and schol$\operatorname{ars}^{27}$ raised. Among the critics, there is overall agreement that the role of "fairness" in competition rules should be furthered. The competition law debate beyond the Atlantic also influenced the attention on fairness in the

\footnotetext{
${ }^{23}$ E.g. Margarethe Vestager, "Fairness and competition" and "Technology with purpose”, 5 March 2020, https://bit.ly/333xOCS.

${ }^{24}$ Margrethe Vestager, "Address at the $10^{\text {th }}$ Annual Global Antitrust Enforcement Symposium: Competition for a fairer society", 20 September 2016, https://bit.ly/2F5PmGn.

${ }^{25}$ In Vestager's view, fairness is the social rationale of competition principles. It involves the balancing of business incentives while ensuring that consumers retain the possibility to arbitrate between competition options. See Damien Gerard, "Fairness in EU competition policy: Significance and implications", Journal of European Competition Law \& Practice 9, no. 4 (2018): 211.

${ }^{26}$ Cfr. Aidan O'Neill, "Competition law and fundamental rights: Some unresolved issues", May 2011, https://bit.ly/2F1CkKe.

${ }^{27}$ Jamie Flattery "Balancing efficiency and justice in EU competition law: Elements of procedural fairness and their impact on the right of a fair hearing", The Competition Law Review 7, no. 1 (2010); D. Daniel Sokol and Andrew T. Guzman, Antitrust Procedural Fairness (Oxford: Oxford University Press, 2019). Flattery has observed that the rules applicable in EU competition proceedings fell short of EU human rights standards in terms of procedural guarantees. Sokol further argued that the "movement to create global best practices had been at a slow pace". See https://bit. ly/32cXdec
} 
EU competition field. In 2016, Hesse ${ }^{28}$ acting US assistant attorney general, stated that "the ultimate goal of antitrust [is] economic fairness".

Fairness is not a new concept in EU competition law. The very wording of Article 101 TFEU saves from invalidity any agreements or decisions between undertakings "allowing consumers a fair share of the resulting benefit", with the conditions that the undertakings are not subject to unnecessary restrictions and that competition is eliminated. Additionally, Article 102 TFEU links the notion of abuse of dominant position to "unfair prices $^{29}$ and trading conditions". What precisely fairness under the Treaty provisions refers to has been extensively discussed in the literature.

As Edwards observed in 1967, the presence of fairness as a concept guiding the EU competition system reflects the trust in public powers typical of European society. In Europe, "Public policy toward restrictions is focused upon fairness in dividing what the economy produces rather than enlargement of product" ${ }^{30}$ More specifically, Amato highlighted that the French, Italian, and German dirigiste traditions highly influenced the European competition regulatory model. Under these traditions, the co-operation of undertakings for the pursuit of a public interest was superior to pure competition as such. ${ }^{31}$ From this perspective, the idea of ensuring "neutral" competition in the market was contrary to the traditional role of public authority in ensuring fairness.

Zimmer ${ }^{32}$ provides further insights into the notion of fairness in the competition field. He describes substantive fairness in EU competition law as concerning not only the consumers but also other players in the market. From his viewpoint, fairness "has a lot to do with the fundamental principle of non-discrimination which is at the basis of most legal systems. The importance of this principle in law probably explains why, even though

\footnotetext{
${ }^{28}$ Renata Hesse, "And never the twain shall meet? Connecting popular and professional visions for antitrust enforcement", 20 September 2016, https://bit.ly/2GzZ4kX.

${ }^{29}$ E.g. Judgment of 14 September 2017, Biedrība Autortiesību un komunicēšanās konsultāciju aǵentūra, C177/16, EU:C:2017:689, paragraphs 31 and ff.

${ }^{30}$ C. D. Edwards, Control of Cartels and Monopolies: An International Comparison (Dobbs Ferry, NY: Oceana Publications, 1967) at 22-3, cited in Hanns Ullrich, The Evolution of European Competition Law: Whose Regulation, Which Competition? (United Kingdom: Edward Elgar Publishing, 2006).

${ }^{31}$ Giuliano Amato, Antitrust and the Bounds of Power: The Dilemma of Liberal Democracy in the History of the Market (Oxford: Hart Publishing, 1997).

${ }^{32}$ Daniel Zimmer, The Goals of Competition Law (United Kingdom: Edward Elgar Publishing, 2012), 74 and ff.
} 
it might not always be justified from a purely economic perspective, the Commission and the Courts remain critical of discriminatory practices".

Padilla $^{33}$ is of the same view as Zimmer and argues that fairness is at the core of EU competition law. For Padilla, fairness comes in the form of dispersion of power, which ensures that bigger companies cannot unduly hamper the commercial activities of small-sized competitors. ${ }^{34}$

The considered authors thus underline that substantive fairness is not merely an intrinsic concept of EU competition rules, but also its ultimate objective. Substantive fairness in EU competition law is not only about market efficiency, but also social justice and, therefore, distribution mechanisms in favour of those in weaker positions, be they consumers or smaller companies. Overall, the substantive notion of fairness in EU competition law appears highly influenced by distributional justice theories, similar to those Rawls developed.

However, contrasting views concerning the role of fairness in the competition sector may be traced in the literature. Other authors have indeed discredited substantive fairness in this sector and have advocated for a conceptualisation of this objective in procedural terms.

For economic efficiency purists, bearers of the core values of the Chicago and Post-Chicago Schools, "the term 'fair' is nothing short of the antitrust $\mathrm{f}$ word". ${ }^{35}$ These scholars argue that contaminating antitrust with fairness considerations would amount to "undesirable arbitrariness in enforcement". ${ }^{36}$ Similarly, Nazzini ${ }^{37}$ makes the point that competition law is only interested with procedural fairness because it does not look at the outcome but at how the outcome has been reached.

\footnotetext{
${ }^{33}$ Christian Ahlborn and A. Jorge Padilla, "From fairness to welfare: Implications for the assessment of unilateral conduct under EC competition law", in European Competition Law Annual 2007: A Reformed Approach to Article 82 EC, ed. Claus-Dieter Ehlermann and Mel Marquis (Oxford: Hart Publishing, 2008).

${ }^{34}$ Substantive fairness in competition law has been theorised in the United States as well by two schools: the discretionalists and the New Brandesians. For a detailed account, see Sandra Marco Colino, "The antitrust F word: Fairness Considerations in competition law", Social Science Research Network, 2018, https://bit.ly/2Gd65I4. "plainCitation”:"Sandra Marco Colino, 'The Antitrust F Word: Fairness Considerations in Competition Law' (Social Science Research Network 2018

${ }^{35}$ Marco Colino, “The antitrust F word"'"plainCitation":"Sandra Marco Colino, 'The Antitrust F Word: Fairness Considerations in Competition Law' (Social Science Research Network 2018.

${ }^{36}$ Ibid, 8-9.

${ }^{37}$ Renato Nazzini, The Foundations of European Union Competition Law: The Objective and Principles of Article 102 (Oxford: Oxford University Press, 2011), 22-23.
} 
Sokol has identified two central elements of procedural fairness in the competition field: transparency and due process. ${ }^{38}$ When competition authorities respect procedural fairness concerns, they create legitimacy "for the competition policy system overall. As a result, strong procedural fairness safeguards force parties to win cases based on the facts and economic evidence". ${ }^{39}$ Furthermore, stressing the importance of procedural fairness in the competition sector, Arena suggests that procedural fairness should be the minimum threshold for international transplants in the field of competition law. ${ }^{40}$

In light of this discussion, two observations arise. First, whereas scholarship is divided on the meaning and role of fairness in competition law, EU primary sources seem to refer to a substantive conception of fairness. Substantive fairness in the competition field ultimately relates to the achievement of a market in which companies and consumers are cooperating to achieve overall wealth in a fair manner. Fairness is pivotal for a pluralistic market, where companies shall not exploit dominant positions and consumers can efficiently use their financial resources. In the years to come, substantive fairness in EU competition law may become more complex and, ultimately, polycentric to incorporate the recent objectives of EU competition policies. ${ }^{41}$

Second, procedural fairness plays a significant role in EU competition law, as extensive scholarship debates and numerous regulatory initiatives of the EU institutions testify. Among the latter, we can cite the adoption of the 2006 guidelines on the fixing of penalties ${ }^{42}$ and the 2011 Commission guidelines on procedural guarantees for parties. ${ }^{43}$

Substantive and procedural fairness in competition law should thus reinforce each other: the enforcement of competition rules should seek to achieve a fair market as defined above, relying on procedural guarantees for

\footnotetext{
${ }^{38}$ D Daniel Sokol, “The new procedural fairness in competition law: Global developments", Journal of European Competition Law \& Practice 10, no. 4 (2019): 197.

${ }^{39}$ Ibid, 197.

${ }^{40}$ Amedeo Arena, "The emergence of a WTO Antitrust jurisprudence through cross-fertilization from other international antitrust institutions: The case for procedural fairness as a necessary precondition", in Procedural Fairness in Competition Proceedings, ed. Paul Nihoul and Tadeusz Skonczny (Cheltenham: Edward Elgar Publishing, 2015), 108 and ff.

${ }^{41}$ Ioannis Lianos, "Polycentric competition law", Current Legal Problems 71, no. 1 (2018).

${ }^{42}$ Commission Guidelines on the method of setting fines imposed pursuant to Article 23(2)(a) of Regulation No. 1/2003.

${ }^{43}$ Commission notice on best practices for the conduct of proceedings concerning Articles 101 and 102 TFEU.
} 
the parties involved in the decision-making process. The following institutions are central in the attainment of substantive and procedural fairness in the EU competition field: the Commission, which identifies violations and sanctions them; and the national and EU courts, which ensure compliance with EU law - including EU fundamental rights - in the context of infringement proceedings and judicial actions. Notably, the EU courts bear on their shoulders the challenging duty of ensuring the achievement of the EU competition objectives laid down in the Treaties, while furthering fairness in the EU in the light of the supreme values and norms of that order. These latter rules also include the Charter of fundamental rights, which currently has the same value as the Treaties. ${ }^{44}$ Charter rights thus contribute to the strengthening of substantive and procedural fairness in the EU competition sector.

\section{Article 47 of the European Union Charter in the field of European Union competition law: how does it contribute to the enhancement of fairness in the enforcement of competition law?}

The application of fundamental rights in the competition field has been extensively studied. Scholars have discussed the relatively limited or significant influence of fundamental rights in the enforcement of EU competition rules, and, in particular, the role of the CJEU in interpreting them. ${ }^{45}$ Authors ${ }^{46}$ agreed on the evident preponderance of procedural-related fundamental rights in the context of EU antitrust litigation and their positive impact on shaping procedural guarantees. However, the growing application of Article 47 Charter and its contribution to ensuring fairness in competition enforcement remains understudied to date. As it will subsequently

\footnotetext{
${ }^{44}$ See Article 6 TEU.

${ }^{45}$ Pieter Van Cleynenbreugel, "Effectiveness through fairness? 'Due process' as an institutional precondition for effective decentralized EU competition law enforcement", $9^{\text {th }}$ ASCOLA Conference Warsaw 2014 on Procedural Fairness in Competition Proceedings, 2014, https://bit.ly/2F9qNZ7; Flattery, "Balancing efficiency".

${ }^{46}$ Flattery, "Balancing efficiency and justice in EU competition law"; Andreangeli, "Competition law", Marco Bronckers and Anne Vallery "No longer presumed guilty? The impact of fundamental rights on certain dogmas of EU competition law", World Competition 34, no. 4 (2011); Carol Harlow and Richard Rawlings, Process and Procedure in EU Administration (Bloomsbury Publishing 2014). However, other authors underplay the effects of fundamental rights in the application of competition rules. See Albert Sanchez Graells and Francisco Marcos, "Human Rights protection for corporate antitrust defendants: Are we not going overboard?”, in Procedural Fairness in Competition Proceedings, ed. Paul Nihoul and Tadeusz Skoczny (Cheltenham: Edward Elgar Publishing, 2015).
} 
be discussed, due to its multi-layered content, this Article contributes to the achievement of both procedural and substantive fairness.

Article 47 Charter enshrines the general principle of effective judicial protection, ${ }^{47}$ which stems from the constitutional traditions common to the Member States and Articles 6 and 13 of the ECHR..$^{48}$ Article 47 grants the right to an effective remedy and the right to a fair trial. The first part of the Article indicates that anyone whose rights deriving from EU law have been breached has the guarantee to an effective remedy under several conditions. First, everyone is entitled to a fair and public hearing that must be held within a reasonable time. Second, the hearing is to be organised by an independent and impartial tribunal established by law. Third, everyone has the right to be advised, defended and represented. Fourth, legal aid must be made available to those who lack sufficient resources.

Under Article 47 of the Charter, the right to an effective remedy and a fair trial are undoubtedly interconnected. However, from an analytical point of view, their objective and purpose are different. The right to a fair trial reflects a collection of procedural guarantees that allow individuals to ascertain and defend their right before courts. These procedural rights ensure the right to be heard by an impartial and independent tribunal. The right to an effective remedy grants an effective redress for the violation of rights. This latter right aims to achieve distributional justice objectives by ensuring that those wronged are restored in their rights and legal entitlements. The right to an effective remedy is thus the consequence and the aspirational outcome of the right to a fair trial, and without a fair trial, an effective remedy cannot be obtained.

For a remedy to be effective, however, the procedural guarantees ensured by the right to a fair trial are not always sufficient. We can envisage cases in which all procedural rules have been respected but violations of rights or interests may not be effectively protected. An EU law textbook example is the case of procedural rules limiting judicial review of measures covering EU law matters. These were the circumstance of the well-known Johnston case. ${ }^{49} \mathrm{Mrs}$. Johnston could not obtain judicial review of an act issued by the UK Secretary of State that was contrary to EU discrimination rules.

\footnotetext{
${ }^{47}$ Judgment of 26 July 2017, Moussa Sacko v. Commissione Territoriale per il riconoscimento della Protezione internazionale di Milano, C-348/16, EU:C:2017:591 paragraph 37.

${ }^{48}$ Judgment of 15 May 1986, Marguerite Johnston v. Chief Constable of the Royal Ulster Constabulary, C-222/84, EU:C:1986:206.

${ }^{49}$ Ibid.
} 
Courts in the UK were precluded under national law from reviewing such acts. Asked to interpret whether the UK rules at stake were compatible with EU law, the ECJ established that although it is up to the national systems to provide procedural rules to access courts, the effective protection of EU derived rights requires the possibility for discriminated individuals to obtain judicial review of administrative decisions before national courts. Johnston clearly indicates that the right to an effective remedy goes beyond the procedural guarantees of the right to a fair trial and focuses on granting a certain threshold of judicial protection to rights. Thus, on a systemic level, the right to an effective remedy requires that justice be done in cases of unlawful conduct violating rights and freedoms deriving from EU law.

Accordingly, while the right to a fair trial undoubtedly enhances procedural fairness in the context of the enforcement of EU competition law, the right to an effective remedy may contribute to substantive fairness in the competition field. From a procedural point of view, the right to a fair trial protected by Article 47 guarantees that the decisions achieved by the EU and national courts, as well as the Commission, are "procedurally sound", i.e. the participatory rights of the parties are respected. From a substantive perspective, the right to an effective remedy under Article 47 Charter contributes to effectively redressing violations of EU competition law and protects EU derived rights and interests. The right to an effective remedy thus becomes particularly important in the field of competition law, where individuals wronged by anti-competitive behaviours may be protected only ex-post, in particular, through judicial proceedings before EU or national courts.

We can identify six main areas in which Article 47 Charter has been applied by EU courts in the competition field: ${ }^{50}$ (a) locus standi and access to a court; (b) the scope of the judicial review by EU courts; (c) the review of penalties by the EU judicature; (d) the excessive duration of proceedings and effective remedies; (d) statement of reasons; (e) evidence. These areas will be discussed below to assess how Article 47 Charter has contributed to the enhancement of fairness in the enforcement of EU competition law.

\footnotetext{
${ }^{50}$ This information is based on the case law research conducted: https://bit.ly/322UiEJ.
} 
(a) Locus standi and access to a court

In the context of the EU courts' case law on competition matters parties have invoked Article 47 Charter to challenge the Plaumann test ${ }^{51}$ applied to assess the locus standi under Article 263 TFEU. However, the ECJ has consistently confirmed its established jurisprudence, whereby the "individual concern" requirement is subject to a narrow interpretation and may not be relaxed to comply with fundamental rights. For instance, in Greenpeace, ${ }^{52}$ the ECJ recalled the division of competences between EU and national courts to ensure effective judicial protection. The Court stated that where individuals cannot lodge an action for annulment before EU courts, it remains the duty of Member States to offer a system ensuring effective remedies in the fields covered by EU law. ${ }^{53}$ In particular, ${ }^{54}$ it is incumbent on the national judges applying EU competition rules to ensure not only their effectiveness but also the protection of the rights stemming therefrom. ${ }^{55}$

Article 47 was also interpreted as entitling both natural and legal persons to bring proceedings before the GC under Article 263(4) TFEU in the absence of a specific legal basis. An interpretation supporting the opposite result would infringe the principle of effective judicial protection. ${ }^{56}$

Furthermore, Article 47 plays a central role in the private enforcement of competition rules before national courts. Interpreted jointly with Article 101 TFEU, Article 47 enables individuals wronged by anticompetitive conducts to claim compensation for the damage suffered when there is a causal link between the said damage and an agreement or practice prohibited by Article 101 TFEU. ${ }^{57}$ Article 47 requires national authorities to

\footnotetext{
${ }^{51}$ Judgment of 15 July 1963, Plaumann \& Co. v. Commission of the European Economic Communities, C-25/62 EU:C:1963:17.

${ }^{52}$ Order of 10 October 2017, Greenpeace Energy eG v. European Commission, C-640/16 P, EU:C:2017:752, paragraphs 23 and ff.

${ }^{53}$ See Judgment of 19 December 2013, Telefónica SA v. European Commission, C-274/12, EU:C:2013:852, paragraphs 56 and ff.

${ }^{54}$ See Judgment of 16 December 2015, Martinair Holland NV. v. European Commission, T-67/11, EU:T:2015:984, paragraph 33.

${ }^{55}$ Judgment of 6 June 2013, Bundeswettbewerbsbehörde v. Donau Chemie and Others, C-536/11, EU:C:2013:366, paragraphs 21-22.

${ }^{56}$ See Judgment of 5 September 2014, Éditions Odile Jacob SAS v. European Commission, T471/11, EU:T:2014:739, paragraph 136.

${ }^{57}$ Judgment of 6 November 2012, Europese Gemeenschap v. Otis and Others, C-199/11, EU:C:2012:684, paragraph 58.
} 
ensure that actions for damages following infringements of competition law provisions effectively redress the violations of competition law. ${ }^{58}$

(b) The scope of the judicial review by European Union Courts

The scope of judicial review under Article 263 TFEU impacts on the discretion left to the Commission and the possibility for private parties to access judicial protection before the GC. The implications of Article 47 are crucial in balancing the right to obtain effective judicial protection against the effectiveness of the Commission's activities. ${ }^{59}$

In Otis, ${ }^{60}$ it was argued that the judicial review under Article 263 TFEU "is insufficient because of [...] the margin of discretion [that] those Courts allow the Commission in economic matters". This implied that the judicial review of EU courts was in breach of the right to an effective remedy under Article 47, as it devolved excessive decisional leeway to the Commission in economic matters. The ECJ found that the margin of discretion of the Commission concerning economic matters "does not mean that the EU Courts must refrain from reviewing the Commission's interpretation of information of an economic nature. Those Courts must [...] not only establish whether the evidence relied on is factually accurate, reliable and consistent but also ascertain whether that evidence contains all the information [that] must be taken into account [...] to assess a complex situation and whether it is capable of substantiating the conclusions drawn from it". It follows that, to comply with Article 47, EU courts must engage in a substantive review of the evidence used by the Commission and verify that the conclusion on the infringement could actually be inferred from the gathered evidence. ${ }^{61}$ The scrutiny of the evidence by the EU judicature ensures that the Commission's discretion to allege competition rules' infringements is subject to limits.

\footnotetext{
${ }^{58}$ The need for effective procedural remedies also flows from Art. 19(1) TEU. For an analysis of the private enforcement mechanisms in the competition field, see Sara Landini, "Private enforcement and market regulation", Market and Competition Law Review II, no. 2 (2018): 53 and ff.

${ }^{59}$ Decisions of the GC may be challenged before the ECJ through the appeal procedure. The former court is solely competent to review the facts of the case, while on appeal the latter court carries only a marginal review. Judgment of 19 December 2013, Siemens AG and Others v. European Commission, C-239/11, EU:C:2013:866, paragraph 41.

${ }^{60}$ Judgment of 6 November 2012, Europese Gemeenschap v. Otis and Others, C-199/11, EU:C:2012:684.

${ }^{61}$ See below.
} 
Article 47 was also pivotal in extending the range of the Commission's acts subject to judicial scrutiny. In Deutsche Ban ${ }^{62}$ the appellant contested before the ECJ the decision of the GC on the ground of a misinterpretation of the right to effective judicial protection. Notably, the appellant criticised the GC for having considered the said right as respected because the Commission's inspection decisions could only be challenged after the inspection occurred. In its judgment, the ECJ rejected this argument and found that the system of judicial review of the Commission's decisions complied with Article 47. It recalled that the inspection decisions of the Commission could be challenged immediately after the company has been notified with the inspection decision, without waiting for the Commission's final decision. Where the EU judicature finds that the Commission has committed irregularity in the conduct of the investigation or if it annuls the inspection decision, any material or evidence gathered during that investigation cannot be used against the company. Under this system, the EU courts ensure that the investigations and conduct of the Commission are procedurally sound while also protecting the procedural guarantees of corporations.

The GC and ECJ have in some instances disagreed on what acts could be included within the scope of Article 263 TFEU. The Stichting Woonpunt case illustrates this tension. ${ }^{63}$ The GC had initially considered that the assessment of the Commission on the compatibility of aid pursuant to Articles 18 and 26 of Regulation 659/1999 remained outside the scope of the review of the EU courts. In this respect, the GC established that the Commission enjoyed a broad margin of discretion to determine the appropriate measures to address the incompatibility of an existing aid scheme with the internal market. As a result, the EU courts should carry a review limited to the manifest errors of assessment in the evaluation of the Commission. The judgment of the GC was subsequently appealed, providing the opportunity to the ECJ to reconsider the scope of the judicial review on this matter.

The ECJ held that that evaluation of the Commission could not be excluded from review by the EU judicature, as doing so would risk undermining

\footnotetext{
${ }^{62}$ Judgment of 18 June 2015, Deutsche Bahn AG and Others v. European Commission, C-583/13, EU:C:2015:404 paragraphs 38 and ff.

${ }^{63}$ Judgment of 15 March 2017, Stichting Woonpunt and Others v. European Commission, C-415/15 P, EU:C:2017:216.
} 
the right to effective judicial protection guaranteed by Article $47 .{ }^{64}$ In particular, the ECJ addressed the question of whether the Commission's letter under Article 17 of Regulation 659/1999 could be challenged before EU courts. This document is considered an intermediate measure before the adoption of a final decision by the Commission on whether a measure constitutes State aid. The Court observed that "Since the Article 17 letter constitutes a first step in the preparation of the decision at issue, the appellants may not be prevented from invoking the unlawfulness of the assessment contained in that letter in support of their action against that decision". ${ }^{65}$ The judgment in Stichting Woonpunt is one of judicial empowerment as it extends the scrutiny of the EU judicature on intermediate acts of the Commission jointly with the Commission's final decision. This decision also empowers corporations to invoke the unlawfulness of intermediate acts issued by the Commission.

The issue of the scope of the judicial review of the EU courts is particularly complex concerning the principle of ne ultra petita. According to this principle, courts adopt a passive stance towards the cases brought before them and decide based only on the pleas submitted by the parties. This principle ensures procedural efficiency and puts on individuals the burden to ask precisely what they want the judge to adjudicate upon. The burden of challenge on the parties is mitigated by the possibility for courts to raise pleas of their own motion, for example, on ordre public issues. In this regard, the British Airways appeal ${ }^{66}$ reaffirmed that the ECJ cannot grant an annulment that goes beyond that sought by the applicant. The Court relied on the principle of res judicata and the effects of the proceedings under Article 263 of the TFEU to exclude the annulment of the parts of EU acts that were not challenged. ${ }^{67}$ As a result, the ECJ found that the GC was correct in annulling only the part of the decision that was challenged at first instance.

\footnotetext{
${ }^{64}$ Ibid, paragraph 39.

${ }^{65} \mathrm{Ibid}$, paragraph 48 .

${ }^{66}$ Judgment of 14 November 2017, British Airways plc v. European Commission, C-122/16, EU:C:2017:861

${ }^{67}$ Ibid, paragraph 82 .
} 
(c) The review of penalties by the European Union judicature

With regard to the penalties for infringements of EU competition law, Article 9(3) of Regulation 1/2003 provides that, in fixing the amount of the fine, the Commission should consider the gravity and the duration of the infringement. ${ }^{68}$ Under Articles 31 of the same Regulation and 261 TFEU, the CJEU has "unlimited jurisdiction to review decisions whereby the Commission has fixed a fine or periodic penalty payment. It may cancel, reduce or increase the fine or periodic penalty payment imposed" 69 . Although the Commission is not a tribunal in the meaning employed in Article 47 Charter, the severity of the fines requires the application of the right to a fair hearing to the procedures concerning infringements of the competition rules applicable to undertakings. ${ }^{70}$ Judgments concerning the review of fines offer interesting reflections on the role of penalties as a form of effective sanction (and remedy), the procedural duties of the parties involved in the review and the division of judicial competences between EU courts.

Notably, the rights included in Article 47 Charter have influenced the standards of review applied for antitrust penalties. The role of Article 47 in this respect became evident in Saint-Gobain. ${ }^{71}$ The case originated from a decision of the Commission sanctioning a set of anti-competitive agreements and concerted practices in the EEA car glass sector. Having challenged the Commission's decision, Saint-Gobain submitted before the GC that the judicial review of fines by the EU courts is not "truly" unlimited, as those courts constrain themselves to identifying manifest errors of assessment or the misuse of powers. Another element hindering the unlimited review of sanctions, according to Saint-Gobain, is that the action for annulment does not have suspensory effect vis-à-vis the fine decision. In its decision on the matter, the GC held that judicial review of the Commission's decisions is complemented by the unlimited review on antitrust penalties. This system offers effective judicial protection as

\footnotetext{
${ }^{68}$ It should be noted that the ECHR case law has established that administrative authorities, such as the Commission, may impose criminal penalties. However, to counterbalance these sanctioning powers, judicial review cannot be limited to the procedural legality of the decision to impose penalties but should consider also the proportionality of the technical choices of the competition authority. See A. Menarini Diagnostics S.R.L. v. Italy (2011), no. 43509/08.

${ }^{69}$ Article 31 of Regulation 1/2003.

${ }^{70}$ Judgment of 27 March 2014, Saint-Gobain Glass France and Others v. European Commission, T56/09 and T73/09, EU:T:2014:160, paragraph 82.

${ }^{71}$ Ibid, paragraphs 79-80.
} 
it allows EU courts, in particular, to substitute their assessment for that of the Commission and, consequently, to cancel, reduce or increase the fine or periodic penalty payment imposed. ${ }^{72}$ When reviewing fines, the EU judicature does not limit itself to marginal scrutiny but engages in a substantive review in light of several factors. These standards of judicial review ensure compliance with the principle of effective judicial review. Nevertheless, the Court did not develop on the absence of suspensory effects when lodging an action of annulment against penalties.

In Hanse \& Rosenthal, ${ }^{73}$ the ECJ further developed on the judicial review of penalties under Article 47. In particular, in the exercise of its unlimited jurisdiction with regard to a fine, the EU judicature is bound, under Articles 261, 263 TFEU and 47 Charter, to examine all complaints based on issues of fact and law that seek to show that the amount of the fine is not commensurate with the gravity or the duration of the infringement. ${ }^{74}$ The GC can also carry out its own assessment on the imposition of fines when it does not find any element alleging illegality of the Commission's decision. ${ }^{75}$ In any event, if the GC does not consider on its own motion the fines under the principles of proportionality, legality and equal treatment, there will be no breach of the principle of effective judicial protection. ${ }^{76}$ One might wonder whether the possibility of the EU judicature not to scrutinise of its own motion the proportionality of the penalties is in line with the Menarini jurisprudence.

The ECJ provided further guidance as to the division of competencies between the GC at first instance and that of the ECJ on appeal concerning fines in the Villeroy appeal. ${ }^{77}$ The ECJ recalled that under Article 47, the GC is solely competent to examine how the Commission assessed the gravity of unlawful conduct and the amount of penalties. The ECJ further

\footnotetext{
${ }^{72}$ Ibid, paragraph 120. This was confirmed in Judgment of 9 June 2016, Repsol Lubricantes $y$ Especialidades and Others v. European Commission, C-617/13, EU:C:2016:416.

${ }^{73}$ Judgment of 16 February 2016, Hansen \& Rosenthal and H«R Wax Company Vertrieb $v$. European Commission, C-90/15, EU:C:2017:123.

${ }^{74}$ See Judgment of 1 February 2018, Deutsche Bahn and Others v. European Commission, C-264/16, EU:C:2018:60; Judgment 18 December 2014, European Commission v. Parker Hannifin Manufacturing et Parker-Hannifin, C-434/13 P, EU:C:2014:2456, paragraph 75.

${ }^{75}$ See Order of 7 July 2016 Westfälische Drahtindustrie GmbH et al v. European Commission, C-523/15, EU:C:2016:541.

${ }^{76}$ Judgment of 22 October 2015, AC-Treuhand AG v. European Commission, C-194/14, EU:C:2015:717, paragraph 77 .

${ }^{77}$ Judgment of 26 January 2017, Villeroy and Boch SAS v. European Commission, C-644/13, EU:C:2017:59.
} 
posited that the exercise of unlimited jurisdiction concerns solely the penalty imposed "and not the entirety of the contested decision". ${ }^{78}$ The GC is thus not required to raise pleas of its own motion, as the unlimited jurisdiction concerning fines is not equivalent to an own-motion review. ${ }^{79}$ Except for public policy grounds, it is the parties' responsibility to raise pleas in law against the first instance decision and adduce relevant evidence. The fact that EU courts do not review in entirety the case of their own motion is not contrary to the principle of effective judicial protection. ${ }^{80}$ Therefore, the parties have the burden to challenge all aspects of penalties they wish to annul. They must offer sufficiently clear and precise information to enable the defendant to prepare its case and allow the court to decide on the matter. ${ }^{81}$

Regarding the role of the ECJ on appeal, the Court focuses its review on two questions. First, "to what extent the GC took into consideration, in a legally correct manner, all the essential factors to assess the gravity of particular conduct in the light of Article 101 [of the] TFEU and Article 23 of Regulation No 1/2003 and, second, [...] whether the GC responded to a sufficient legal standard to all the arguments raised in support of the claim for reduction of the fine". ${ }^{82}$

Concerning the first assessment, the ECJ ${ }^{83}$ must evaluate whether the GC paid sufficient attention to different factors, such as, among others, the conduct of the undertaking, the profit that the companies were able to derive from it, the value of goods concerned and the threat that infringements pose to the objective of the EU. Although the financial situation of the applicants is not a criterion for the review of a fine, an undertaking's ability to pay can be relevant only in a specific social context, namely, when the fine can lead to an increase in unemployment or a deterioration in the economic sectors upstream and downstream of the undertaking

\footnotetext{
${ }^{78}$ Ibid, paragraph 75 .

${ }^{79}$ Ibid.

${ }^{80}$ Judgment of 28 June 2016, Portugal Telecom SGPS, SA v. Commission, T-208/13, EU:T:2016:368, paragraph 275. For an analysis of this case, see Catarina Vieira Peres "Developments in the case law of the EU courts in competition law in 2016", Market and Competition Law Review I, no. 1 (2017): 197 and ff.

${ }^{81}$ Ibid, paragraph 270.

${ }^{82}$ Judgment of 26 January 2017, Villeroy and Boch SAS v. European Commission, C-644/13, EU:C:2017:59, paragraph 72 .

${ }^{83}$ See Judgment of 8 December 2011, KME Germany AG et al v. European Commission, C-272/09 C, EU:C:2011:810.
} 
concerned.$^{84}$ Yet the ECJ cannot substitute, on grounds of fairness, its own assessment for that of the GC when the latter court exercises its unlimited jurisdiction to rule on the amount of competition fines imposed on undertakings. ${ }^{85}$ The ECJ may nevertheless find that an error of law has been committed by the GC when the level of the "penalty is not merely inappropriate, but also excessive to the point of being disproportionate". ${ }^{86}$

In light of these parameters, in Villeroy, the ECJ observed that the GC did not limit itself to ruling on the legality of the amount but also reviewed the fine in light of the gravity of the infringement. Moreover, the ECJ noted that the infringement committed by the company, which included "horizontal price-fixing, market-sharing and output-limitation agreements, which [were typically] secret, [were] [...] among the most harmful restrictions of competition". Consequently, the ECJ found that the GC had correctly scrutinised the fines imposed by the Commission. ${ }^{87}$

Villeroy is a significant judgment, as it confirms that the GC is the main court in charge of this review, due to its competence to assess the facts in addition to the law of the cases. At the same time, the ECJ has also significant leeway for detecting errors committed by the GC in this context. To do so, an implicit assessment of the fines may be inevitable. One may wonder whether in case the ECJ identifies an error of law by the GC in the review of fines, the former court could give the final judgment ${ }^{88}$ and thus itself pronounce on the amount of penalties. ${ }^{89}$ It is submitted that the answer to this question depends on the type of assessment that the ECJ would have to carry. According to the division of competencies between the GC and the ECJ, only in case of "non-complex" assessment can the ECJ pronounce its final decision..$^{90}$

\footnotetext{
${ }^{84}$ See Order of 7 July 2016, Westfälische Drahtindustrie GmbH v. European Commission, C-523/15, EU:C:2016:541, paragraph 46; Judgment of 29 June 2006, SGL Carbon v. Commission of the European Communities, C-308/04 P, EU:C:2006:433 paragraph 106.

${ }^{85}$ Judgment of 26 January 2017, Villeroy and Boch SAS v. European Commission, C-644/13, EU:C:2017:59, paragraph 184.

${ }^{86} \mathrm{Ibid}$

${ }^{87}$ Ibid, paragraph 188 . However, the excessive duration of administrative proceedings may breach the right of defence of the companies. The ECJ further held that the excessive duration of the administrative procedure before the Commission cannot lead to the reduction of fines imposed.

${ }^{88}$ Article 61 ECJ Statute.

${ }^{89}$ This occurred in pre-Lisbon case law and before the entry into force of Regulation 1/2003, e.g. Baustahlgewebe GmbH discussed below.

${ }^{90}$ See Giulia Gentile, "The ECJ as the EU Court of Appeal: Some evidence from the appeal case-law on the non-contractual liability of the EU", Review of European Administrative Law 13, no. 1 (2020).
} 
Finally, in Schenker, ${ }^{91}$ the ECJ evaluated on appeal whether the GC had paid sufficient attention to the harm caused by the sanctioned infringement when reviewing the amount of penalties imposed, as required by Article 47. The ECJ confirmed the first instance judgment by stating that the role of fines is that of "general deterrence" and, accordingly, may not exactly reproduce the economic harm "which has been, or which may have been caused by the cartel concerned". ${ }^{2}$ As a result, the Commission is not obliged to impose penalties that reflect the economic harm caused in the form of the surcharges levied; however, it can take into account the value of sales of goods or services to which the infringement directly or indirectly relates. ${ }^{93}$

Overall, building on the unlimited jurisdiction stemming from Article 261 TFEU, both the GC and the ECJ apply rather intense scrutiny on the matter under the aegis of Article 47. Through its review, the EU judicature may determine whether the fines imposed are effective sanctions and thus protect the general interest in a fair competition.

(d) The excessive duration of proceedings and effective remedies

According to Article 47(2) of the Charter, a fair trial includes reaching a final decision within a reasonable time. Interestingly, the principle of "reasonable duration" stemming from Article 47 is also applicable in the context of administrative procedures relating to competition policy before the Commission..$^{94}$ A series of judgements in the field of competition litigation addressed what constitutes a "reasonable duration" of proceedings under Article 47.

In Baustahlgewebe $G m b H,{ }^{95}$ which was decided before the entry into force of the Charter, the ECJ relied on procedural economy grounds to annul on appeal a GC's decision in breach of a reasonable duration of proceedings. Contextually, to redress this violation by the GC, the ECJ reduced the amount of the fines imposed by the Commission on an undertaking.

\footnotetext{
${ }^{91}$ Judgment of 1 February 2018, Schenker Ltd v. European Commission, C-263/16, EU:C:2018:58.

${ }^{92}$ Ibid, paragraph 65.

${ }^{93} \mathrm{C}-263 / 16 \mathrm{P}-$ Schenker v. Commission. To the same effect see also Judgment of 1 February 2018, Kühne + Nagel International and Others v. Commission, C-261/16, EU:C:2018:56.

${ }^{94}$ Judgment of 5 June 2012, Imperial Chemical Industries v. European Commission, T-214/06, EU:T:2012:275.

${ }_{95}$ Judgment of 17 December 1998, Baustahlgewebe v. Commission of the European Communities, C-185/95 P EU:C:1998:608.
} 
In the recent cases Kendrion ${ }^{96}$ and Gascogne, ${ }^{97}$ the ECJ reversed this case law. In these appeals, the ECJ had to consider, once again, a fine reduction claim following excessively long proceedings before the GC. Surprisingly, the ECJ declared as inadmissible pleas alleging the excessive duration of proceedings before the GC. It held that to sanction violations of Article 47(2) of the Charter, parties should bring an afresh action for damages before the GC. The ECJ also laid down the principles to be followed by the GC in the assessment of the damage caused by the unreasonable duration of proceedings. Among these, the ECJ mentioned the complexity of the case, the dilatory conduct of the parties and the principle of legal certainty. The Court stressed that this list is not exhaustive and that the assessment must be carried out in light of the circumstances specific to the case. However, the EU judicature should not take into account the financial situation of the requesting party. ${ }^{98}$ The ECJ applied these principles in the cases at hand and found that the GC had breached the reasonable duration of the proceedings at first instance. Nonetheless, the plea had to be rejected since the competent court to adjudicate on damages caused by the excessive length of proceedings is the GC under Article 340 TFEU. Following Kendrion and Gascogne, pleas raised on appeal alleging the excessive length of proceedings have consistently been dismissed. ${ }^{99}$

The ECJ has also specified that the action for damages to sanction excessively long proceedings should be assigned to a different chamber than the one that adjudicated in the first instance. ${ }^{100}$ In any event, the excessive length of proceedings cannot lead to the annulment of the decision issued by the GC nor the reduction of the fine imposed: ${ }^{101}$ in the ECJ's view,

\footnotetext{
${ }^{96}$ Judgment of 26 November 2013, Groupe Gascogne v. European Commission, C-58/12, EU:C:2013:770.

${ }^{97}$ Judgment of 26 November 2013, Kendrion NV. v. European Commission, C-50/12, EU:C:2013:771.

${ }^{98}$ Judgment of 26 November 2013, Kendrion NV. v. European Commission, C-50/12, EU:C:2013:771 and Judgment of 26 November 2013, Groupe Gascogne v. European Commission, C-58/12, EU:C:2013:770, paragraphs 99 and ff.

${ }^{99}$ See Judgment of 14 September 2016, Trafilerie Meridionali v. European Commission, C-519/15 P, EU:C:2016:682, paragraph 62, Judgment of 26 January 2017, Aloys F. Dornbracht v. European Commission, C-604/13, EU:C:2017:45, paragraph 97, Judgment 12 January 2017, Timab Industries and Cie financière et de participations Roullier (CFPR) v. European Commission, C-411/15 P, EU:C:2017:11, paragraph 165.

${ }^{100}$ Judgment of 26 November 2013, Groupe Gascogne v. European Commission, C-58/12, EU:C:2013:770, paragraph 90.

${ }^{101}$ See Judgment of 14 September 2016, Ori Martin v. European Commission, C-490/15, EU:C:2016:678 paragraph 116; Judgment of 9 October 2014, ICF v. European Commission,
} 
the annulment cannot remedy the violation of the reasonable duration requirement. ${ }^{102}$ Furthermore, although parties are not requested to adduce any additional evidence on appeal when lamenting an excessive duration of the proceedings, the ECJ may note the occurred violation. Parties are also exonerated from adducing further evidence in a new action for damages before the GC in case the ECJ confirms on appeal the presence of a violation of Article 47(2). ${ }^{103}$

\section{(e) Statement of reasons}

It is well established that Article 47 Charter and the principle of effective judicial protection are linked to the duty of EU institutions to provide a statement of reasons in their acts. ${ }^{104}$ The statement of reason ensures double protection, as it allows individuals to challenge the grounds of a decision adopted by the EU institutions and permits EU courts to exercise their judicial review over EU acts.

In the context of competition law, Article 47 "requires that the operative part of a decision [...] by the Commission [...] must be particularly clear and precise and that the undertakings held liable [...] must be in a position to understand and to contest that imputation of liability and the imposition of those penalties, as set out in the wording of that operative part". ${ }^{105}$ The Commission should specify the nature, the extent of the sanctioned infringement and the liable entities. ${ }^{106}$ This information is necessary to treat requests for damages following the infringement. Only when the operative part is unclear can the statement of reasons contained in a decision be considered. ${ }^{107}$

The Club Hotel Loutraki ${ }^{108}$ offers insights on the duty to state reasons on the part of the Commission under Article 47. The case stemmed from a

C-467/13 paragraphs 55-61; Judgment of 9 June 2016, PROAS v. European Commission, C-616/13 P, EU:C:2016:415, paragraphs 81-86; Judgment of 5 June 2012, Imperial Chemical Industries $v$. European Commission, T-214/06, EU:T:2012:275, paragraphs 286-287.

${ }^{102}$ Judgment of 9 June 2016, CEPSA v. European Commission, C-608/13, EU:C:2016:414, paragraph 71 .

${ }^{103}$ Ibid.

${ }^{104}$ Article 296 TFEU.

105 Judgment of 12 July 2019, Sony Optiarc and Sony Optiarc America v. European Commission, T-763/15, EU:T:2019:517, paragraph 225.

${ }^{106}$ Judgment of 16 December 2015, Air France v. European Commission, T-63/11, EU:T:2015:993.

107 Ibid.

${ }^{108}$ Judgment of 21 December 2016, Club Hotel Loutraki AE et al. v. European Commission, C-131/15

P, EU:C:2016:989. 
notification by the Greek authorities of measures in favour of Club Hotel Loutraki. The Commission concluded that the notified arrangements did not constitute State aid within the meaning of Article 107(1) TFEU. The matter was brought before the EU judicature. On appeal, the appellants submitted that the GC erred in considering that the Commission had not infringed the duty to state reasons. For our analysis, it should be noted that the Commission had redacted almost all economic evaluations; for this reason, the applicants argued that they could not effectively challenge the Commission's decision.

The ECJ concurred with the GC and held that the breach of the statement of reasons by the Commission was not proved. ${ }^{109}$ In the opinion of the Court, the appellants had failed to explain the importance of the omitted data from the non-confidential version of the decision. The absence of economic data did not impede the applicants from understanding the reasoning followed by the Commission nor did it hinder their ability to challenge that decision before the Court and the possibility for the EU courts to ensure effective judicial protection. This outcome is surprising, since the exclusion of economic data may limit the possibility for third parties to challenge the details of the Commission's decision. Moreover, the duty to prove the usefulness of non-disclosed economic data can amount to a probatio diabolica.

\section{(f) Evidence}

Evidence in competition law is of essence. As stated by Kalintiri, "evidence standards constitute an intrinsic element of what makes a trial 'fair"'. ${ }^{110}$ The burden of proof for the Commission and the parties involved in competition infringement proceedings was delineated in several decisions.

First, in Hanse \& Rosenthal, ${ }^{111}$ the ECJ established that while the Commission must submit proof of violations, the company must raise a defence against the finding of a breach of competition rules to provide evidence that the conditions for applying the rule from which this defence was deduced had been met. If the parties meet the required evidence

\footnotetext{
${ }^{109}$ Ibid, paragraph 55.

${ }^{110}$ Andriani Kalintiri, Evidence Standards in EU Competition Enforcement (Oxford: Hart Publishing, 2019), 2.

${ }^{111}$ Judgment of 16 February 2017, Hansen \& Rosenthal and Her Wax Company Vertrieb v. European Commission v. European Commission, C-90/15, EU:C:2017:123.
} 
thresholds, the Commission will have to resort to other evidence to establish an infringement. Moreover, the factual elements relied on, either by the Commission or a company should be such as to oblige the other party to provide an explanation or justification, failing which it is permissible to conclude that the rules on the burden of proof have been satisfied.

Furthermore, in Siemens $A G,{ }^{112}$ the ECJ recalled its established case law according to which the Commission should (in compliance with the right to a fair hearing) allow the parties involved in the infringement proceedings to make known their views on the facts, objections and circumstances put forward by the Commission. However, in an administrative procedure such as that provided for infringements in the field of competition law, the Commission is not obliged to allow cross-examination of the witnesses it heard. Companies can challenge the legitimate refusal of the Commission to allow such cross-examination before the GC. It will be for the EU courts, which enjoy the maximum discretion in this area, to assess the relevance of the application to the subject matter of the dispute and the need to examine the witnesses named.

The Commission is also in charge of deciding the relevance of access to the evidence used in competition infringements. ${ }^{113}$ However, if a document in the Commission's possession that may be categorised as exculpatory evidence for an undertaking is not communicated to that company, the latter's defence rights are infringed if it shows that the document at issue could have been useful for its defence. Therefore, applicants alleging a breach of the right to a defence because of a violation of the right to access documents must provide prima facie evidence that undisclosed documents will be useful to their defence.

In $H \& R$, the GC also held that Article 47 does not grant an absolute right to admit a witness. The right to a fair process merely includes the possibility for the suspect to contest, adequately and sufficiently, the allegation presented against him. ${ }^{114}$ Concurrently, the GC adopted an extensive interpretation of the right to use "unlawful" evidence by the Commission. In Goldfish $B V{ }^{115}$ the GC held that evidence lawfully obtained by the

\footnotetext{
112 Judgment of 19 December 2013, Siemens v. European Commission, C-239/11, EU:C:2013:866, paragraphs 318 and ff.

${ }^{113}$ Judgment of 12 July 2018, NKT Verwaltungs GmbH v. European Commission, T-447/14, EU:T:2018:443.

${ }^{114}$ Judgment of 16 February 2017, Hansen \& Rosenthal and H«R Wax Company Vertrieb $v$. European Commission, C-95/15, EU:C:2017:125.

${ }^{115}$ Judgment of 8 September 2016, Goldfish and Others v. Commission, T-54/14, EU:T:2016:455.
} 
Commission, which may have been previously gathered unlawfully by third parties, could be relied upon. According to the GC, the use of unlawful evidence did not contravene, in the context of criminal proceedings, the fairness requirement established in Article 6 ECHR, protecting the right to a fair trial. This latter provision shapes the interpretation of Article 47 Charter. ${ }^{116}$

The question about the evidence that must be used in infringement proceedings is intertwined with the presumption of innocence. This procedural guarantee becomes particularly relevant in relation to infringement of competition rules, which can result in severe penalties. ${ }^{117}$ In this respect, it should be noted that the GC has considered this presumption as stemming from Article 47, despite Article 48 of the Charter laying down the right to a defence. Interestingly, parties can obtain an annulment from EU courts of the Commission's decisions finding infringement if they can disprove alleged anti-competitive behaviour. However, in recent cases the ECJ has reaffirmed that the evidence to be used by the Commission must meet certain threshold of accuracy. ${ }^{118}$ Yet, the rule remain that companies are de facto presumed guilty, at least in relation to 102 TFEU infringements. ${ }^{119}$

\section{Fairness in the field of competition law under Article 47: an assessment}

The considered case law confirms that fundamental rights are increasingly dominant in the enforcement of EU competition law and are shaping the standards regarding fairness in the EU competition framework. The analysis of the EU case law further highlights the significant impact of Article 47 Charter in the enforcement of EU competition law. ${ }^{120}$ This provision has provided manifold contributions to the enforcement of EU competition law, both from a procedural and substantive fairness perspective.

From a procedural perspective, Article 47 has been used to clarify the procedural guarantees and obligations of corporations, in parallel with the duties of the European Commission and the judicial review by EU courts. From a substantive perspective, Article 47 Charter has furthered

\footnotetext{
${ }^{116}$ Ibid, paragraph 144 .

${ }^{117}$ Judgment of 12 June 2014, Intel v. European Commission, T-286/09, EU:T:2014:547, paragraph 63.

${ }^{118}$ Judgment of 28 November 2019, ABB Ltd. and ABB AB v. European Commission, C-593/18, EU:C:2019:1027.

${ }^{119}$ Judgment of 6 September 2017, Intel v. European Commission, C-413/14 P, EU:C:2017:632

${ }^{120}$ This view is shared by Andreangeli, "Competition law".
} 
the opportunity for individuals to obtain judicial protection and, accordingly, effective remedies. In addition, this provision has strengthened EU courts' competence regarding the unlimited review of fines, thereby contributing to one of the most significant areas for the enforcement of EU competition law.

\subsection{Article 47 and procedural fairness}

In terms of procedural fairness, under Article 47 companies should submit comprehensive evidence to disprove the finding of the Commission concerning the infringement of competition rules. ${ }^{121}$ Notably, this also includes explaining how the information or document not shared by the Commission would have been helpful to discharge the company. ${ }^{122}$ In other words, applicants alleging a breach of the right to a defence because of a violation of the right to access documents must provide prima facie evidence that undisclosed documents will be useful to their defence. However, companies are de facto presumed guilty, as they have to disprove the evidence submitted by the Commission, in particular, in cases relating to Article 102 TFEU. In particular, they will have to demonstrate how the infringement did not take place. This may require a probatio diabol$i c a$, and demonstrating how unknown information may have been useful for protecting the position of corporations. Merely raising the possibility that the evidence used by the Commission is incomplete will not be sufficient for shielding the liability of the parties. ${ }^{123}$ Therefore, corporations do not enjoy a presumption of innocence. Whether this is compatible with Article 48 Charter is controversial. This has been the subject of several criticisms in the literature. ${ }^{124}$ The following observations shall be made in this regard. First, such a high evidence threshold under Article 47 for companies reflects the powerful role of the Commission in the competition field. Second, the fundamental rights of legal and not natural entities are at stake. The extent to which corporations should receive the same

\footnotetext{
${ }^{121}$ Judgment of 16 February 2017, Hansen \& Rosenthal and H\&R Wax Company Vertrieb $v$. European Commission, C-90/15, EU:C:2017:123.

${ }^{122}$ Judgment of 12 July 2018, NKT Verwaltungs GmbH v. European Commission, T-447/14, EU:T:2018:443.

${ }^{123}$ Judgment of 21 December 2016, Club Hotel Loutraki AE et al. v. European Commission, C-131/15

P, EU:C:2016:989.

${ }^{124}$ Aidan O’ Neill, “Competition law”; Bronckers and Vallery, "No longer presumed guilty?”.
} 
protection, as natural persons remain debatable. ${ }^{125}$ Possible drawbacks of extending the protection granted to natural persons to corporations are both practical and philosophical: if companies are provided with the same legal guarantees as natural individuals, the latter will be deprived of their "special" protection and position in society through human rights. It is the view of the author that the application of fundamental rights to legal entities should bear in mind the very nature of these bodies and ensure that the position of the natural individual in the society is protected.

Furthermore, Article 47 does not entitle obtaining the total annulment of the Commission's acts when some aspects of these measures have not been challenged. ${ }^{126}$ Consequently, corporations will have to submit all pleas they wish to raise, since they cannot rely on the ex officio powers of the Court. Additionally, companies enjoy a (restrained) right to be heard in the context of infringement proceedings. ${ }^{127}$

Regarding the Commission, Article 47 imposes several procedural duties but also allows broad discretionary powers. Although this institution is not a tribunal for Article 47, it is subject to the respect of the guarantees stemming from that Article, also when carrying its investigations. ${ }^{128}$ First, due to the seriousness of the fines it can impose, the right to a fair hearing applies to Commission proceedings in the field of competition law. ${ }^{129}$ In principle, as required under the right to a fair trial, this institution should afford the possibility for the parties involved to be heard. However, in case the Commission does not allow the right to be heard to the parties, said parties may nevertheless obtain judicial protection through the challenging of its decisions in compliance with Article $47 .{ }^{130}$ Second, the Commission should also comply with Article 47 in the adoption of final decisions, specifically, when drafting the operative part of the final

\footnotetext{
${ }^{125}$ Peter Oliver, "Companies and their fundamental rights: A comparative perspective", International and Comparative Law Quarterly 64, no. 3 (2015): 661, Anna Grear, Redirecting Human Rights: Facing the Challenge of Corporate Legal Humanity (United Kingdom: Palgrave Macmillan Limited 2010); Graells and Marcos, "The EU's accession”.

${ }^{126}$ Judgment of 14 November 2017, British Airways v. European Commission, C-122/16, EU:C:2017:861.

${ }^{127}$ Ibid.

${ }^{128}$ Judgment of 27 March 2014, Saint-Gobain Glass France and Others v. European Commission, T56/09 and T73/09, EU:T:2014:160.

${ }^{129}$ Ibid.

${ }^{130}$ Judgment of 18 June 2015, Deutsche Bahn and Others v. European Commission, C-583/13, EU:C:2015:404.
} 
decisions, which must be clear and include a series of elements. ${ }^{131}$ However, Article 47 does not restrict the Commission's wide discretion regarding the evidence to be used to prove anticompetitive behaviours. ${ }^{132}$ This institution may even use evidence lawfully obtained but previously gathered by a third party in breach of fundamental rights. ${ }^{133}$

Concerning the EU courts, Article 47 does not require the EU judicature to have an active role in providing justice but merely to adjudicate upon pleas submitted by the parties. ${ }^{134}$ Furthermore, as the ECJ observed, the fact that EU courts do not consider, of their own motion, all aspects of the possible illegality of fines or the challenged decisions does not lead to violations of Article 47 Charter. ${ }^{135}$ However, the EU judicature has been reluctant to ensure procedural fairness when it comes to the excessive duration of proceedings. ${ }^{136}$ The EU courts have argued that the rights stemming from Article 47(2) may be protected only via a new action before the GC and not as on appeal. ${ }^{137}$ Procedurally speaking, the evidence to be submitted by the parties will be limited if the ECJ already observed, in a precedent appeal, that the GC had objectively concluded the proceedings in an unreasonable time. ${ }^{138}$ Yet, while violations have been acknowledged, ultimate decisions granting compensation due to the conduct of the GC have not been issued to date. This was due to the application of a manifest error threshold when assessing the conduct of the GC. ${ }^{139}$ As a result, the EU judicature may negatively affect the perception of the public and the parties involved in proceedings regarding the effectiveness of the decisionmaking processes of the Luxembourg judges. This is an area in which the current interpretation of Article 47 Charter does not match the procedural fairness aspirations stemming from that very provision.

\footnotetext{
${ }^{131}$ Judgment of 12 July 2019, Sony Optiarc and Sony Optiarc America v. Commission, T-763/15, EU:T:2019:517, paragraph 225.

${ }^{132}$ Judgment of 12 July 2018, NKT Verwaltungs GmbH v. European Commission, T-447/14, EU:T:2018:443.

${ }^{133}$ Judgment of 8 September 2016, Goldfish and Others v. European Commission T-54/14, EU:T:2016:455.

${ }^{134}$ Judgment of 14 November 2017, British Airways v. European Commission, C-122/16, EU:C:2017:861.

${ }^{135}$ Judgment of 22 October 2015, AC-Treuhand v. Commission, C-194/14, EU:C:2015:717.

${ }^{136}$ For example, Judgment 13 December 2018, European Union v. Gascogne Sack Deutschland and Gascogne, C-138/17 P, EU:C:2018:1013.

${ }^{137}$ Ibid.

${ }^{138}$ Judgment of 9 June 2016, CEPSA v. European Commission, C-608/13, EU:C:2016:414.

${ }^{139}$ Gentile, “The ECJ”, 100.
} 


\subsection{Article 47 and substantive fairness}

From a substantive fairness perspective, Article 47 Charter has contributed to strengthening effective remedies in the field of EU competition law. This provision has influenced the possibility of obtaining judicial protection before EU courts concerning a broad range of Commission's acts. The EU Courts are also required under Article 47 to verify that the evidence used by the Commission in economic matters is factually accurate. ${ }^{140}$ Although this provision cannot relax the admissibility and locus standi requirements of Article 263 TFEU, ${ }^{141}$ Article 47 was interpreted by EU courts to allow annulment not only of the Commission's decisions but also of the evidence relied upon by that institution. This is a crucial evolution in the EU competition law system: individuals are now better positioned to address infringement proceedings before the EU courts. The principle of effective judicial protection enshrined in Article 47 allows challenging, among others, the decisions of the Commission concerning investigations $^{142}$ and the preliminary acts of State aid investigations jointly with the Commission's final decisions. ${ }^{143}$

Furthermore, the ECJ has established that the GC is the competent court to redress violations of Article 47(2) Charter through the action for damages (Article 340 TFEU). ${ }^{144}$ It should be noted, however, that this recent jurisprudence reversed previous case law that entitled parties to allege a violation of excessively long proceedings before the GC during appeal proceedings before the ECJ , without bringing a new claim under Article 340 TFEU. As such, this new case law is more restrictive and reduces procedural economy guarantees for corporations.

Another area where Article 47 has contributed to the enhancement of substantive fairness is the review of fines for anticompetitive conducts. Fines are one of the tools used by the Commission to sanction anti-competitive conducts. Their role is therefore deterrent and additional to the structural and behavioural remedies that the Commission may impose

\footnotetext{
${ }^{140}$ Judgment of 6 November 2012, Europese Germeenschap v. Otis and Others, C-199/11, EU:C:2012:684.

${ }^{141}$ See Order of 10 October 2017, Greenpeace Energy v. European Commission, C-640/16 P, EU:C:2017:752.

${ }^{142}$ Judgment of 18 June 2015, Deutsche Bahn and Others v. European Commission, C-583/13, EU:C:2015:404.

${ }^{143}$ Judgment of 15 March 2017, Stichting Woonpunt and Others v. European Commission, C-415/15

P, EU:C:2017:216.

${ }^{144}$ Judgment of 26 November 2013, Kendrion NV. v. European Commission, C-50/12, EU:C:2013:771.
} 
on undertakings for competition infringements. ${ }^{145}$ In this sense, penalties may be conceptualised as a form of remedy to protect the general interest of the EU in a fair competition within the internal market. The substantive review of fines, demanded under Regulation 1/2003 and Article 261 TFEU, is instrumental for ensuring effective judicial review, one of the essential components of the principle of effective judicial protection as enshrined in Article 47 Charter. Notably, the GC is in charge of carrying out an indepth analysis of the appropriateness of the penalties to provide an effective review. ${ }^{146}$ On appeal, the ECJ considers whether the GC has paid sufficient attention to the different factors related to the review of a fine and whether the GC sufficiently argued its decision to review or modify the fine. ${ }^{147}$ Although the ECJ cannot substitute the GC findings on grounds of fairness, it can find that that GC committed an error when two conditions are met, i.e. penalty is not merely inappropriate, but also excessive to the point of being disproportionate. ${ }^{148}$ While the EU courts have been criticised for leaving a significant margin of discretion to the Commission in terms of imposing, for example, commitments, ${ }^{149}$ the review of penalties enables substantive fairness considerations. The EU judicature can indeed balance the amount of the fine with the infringement proved by the Commission, and amend the penalty imposed, if necessary.

To avoid infringing both Article 47 requirements and the objectives of substantive fairness in competition fields, the EU courts should not hesitate to express their views on the activity of the Commission when setting fines. This role of the EU courts is even more important in light of the deterrent role of these penalties and the fact that they constitute a form of "remedy" for violations of EU competition law. It is true that Article 47 reinforces (and continues to reinforce) the unlimited jurisdiction of the EU judicature in the field of penalties review. One cannot, however, exclude a spill over effect in which substantive fairness considerations prompted by Article 47 Charter in the review of penalties may also extend to other remedial areas of EU competition enforcement. In this context, the commitments imposed by the Commission may also be conceptualised as

\footnotetext{
${ }^{145}$ See Article 7 of Regulation 1/2003.

${ }^{146}$ Judgment of 26 January 2017, Villeroy and Boch SAS v. Commission, C-644/13, EU:C:2017:59.

${ }^{147}$ Ibid; Judgment of 1 February 2018 Schenker v. Commission, C-263/16 EU:C:2018:58.

${ }^{148}$ Judgment of 3 September 2009, William Prym GmbH \& Co. KG and Prym Consumer GmbH \& Co. KG v. Commission of the European Communities, C-534/07 P, EU:C:2009:505, paragraph 86.

${ }^{149}$ Ryan Stones, "Commitment decisions in EU competition enforcement: Policy effectiveness v. the formal rule of law", Yearbook of European Law 38 (2019): 361-399.
} 
remedies protecting the general interest, and, as such, should be subject to in-depth judicial scrutiny by the EU courts. ${ }^{150}$

The right to an effective remedy under Article 47 should not, however, become void when it comes to sanctioning excessively long proceedings. The duty of the parties, as identified in recent case law, to bring a separate action for damages before the GC following the violation of Article 47(2) Charter is procedurally correct; it discharges the ECJ from reconsidering the facts of the case, which is left to the competence of the GC. Yet this new case law reduces the economic procedural guarantees in favour of individuals, who can now obtain redress for breaches of Article 47(2) only by lodging a new claim once the excessively long proceedings have been concluded. More worryingly, at the time of writing, recent claims for damages for excessively long proceedings have been unsuccessful, even if breaches of Article 47(2) Charter were identified. ${ }^{151}$

It should also be noted that Article 47 Charter was further interpreted as requiring national authorities to effectively ensure the redress of violations of competition law via actions for damages. ${ }^{152}$ This requirement stems from Directive 2014/104, which regulates this type of action before national courts. In this context, national courts become the ultimate provider of effective remedies following the violation of EU competition rules. When granting such remedies, national judges should strictly cooperate with the ECJ in setting the threshold of effective judicial protection required by Article 47 .

Although the implications of Article 47 Charter are beneficial for increasing the overall fairness of the enforcement of EU competition law, this paper submits that there is scope for improvement. The EU courts should not miss the opportunity to make use of this provision to ensure the achievement of both procedural and substantive fairness in the enforcement of EU competition law.

\footnotetext{
${ }^{150}$ The use of Article 47 Charter "against" individuals.

${ }^{151}$ See Judgment of 13 December 2018, European Union v. Gascogne Sack Deutschland and Gascogne, C-138/17 P EU:C:2018:1013.

${ }_{152}$ Judgment of 6 June 2013, Bundeswettbewerbsbehörde v. Donau Chemie and Others, C-536/11, EU:C:2013:366.
} 


\section{Conclusion}

This paper discussed the contribution of Article 47 of the EU Charter of Fundamental Rights to the enhancement of fairness in the enforcement of EU competition law. Prior to engaging in this analysis, the paper has illustrated various notions of fairness in reference to existing literature and legal areas. Broadly speaking, we may distinguish between "substantive" and "procedural" fairness. While the former guarantees that the overall impact of policies is democratically sound, i.e. acceptable to the community of reference and with a general benefit for the citizens, procedural fairness is concerned with ensuring the effective participation of entities in decision-making processes. These two notions are encountered in the field of competition. In particular, substantive fairness aspirations are present in both legislative sources and in the political statements of the European Commission concerning competition matters. This notion is traditionally influenced by continental European traditions, whereby public authorities should ensure distributional fairness in the market. This involves protecting those in a weaker position, in compliance with the principles of equality and non-discrimination. Procedural fairness also has a central role in EU competition law, since it ensures sound administrative conduct by the Commission and EU courts and the effective participation of corporations in reaching infringement decisions. Procedural fairness in the competition field is protected by various instruments, such as Regulation 1/2003 and the Commission's notices on procedural rights.

Against this background, this article has discussed the impact of Article 47 of the Charter, being the most cited fundamental right in EU litigation on competition matters, in enhancing fairness in the enforcement of EU competition rules. There are six areas in which this provision was extensively applied, i.e. locus standi, the scope of the judicial review, the review of penalties, the excessive duration of proceedings, the duty to state reasons and evidence. The article has subsequently distinguished between the impact of this provision on procedural and substantive fairness in the competition field by reference to individuals, the Commission and the EU courts. The analysis confirmed the procedural contribution to fairness in the context of Article 47 in the competition field. However, interesting findings as to the contribution of this provision towards achieving substantive fairness in the competition field were also presented. Notably, Article 47 Charter expands the possibility for reviewing the Commission's acts, shapes the right to an effective remedy in conjunction with excessively 
long proceedings, and strengthens substantive fairness considerations via the review of penalties conducted by EU courts, in particular, the GC. Overall, a possible spillover effect of Article 47 requirements regarding the review of penalties in other areas of EU competition is not implausible and should be strongly welcomed, based on the need for achieving substantive fairness in the field of EU competition law.

\section{Bibliography}

Ahlborn, Christian and A. Jorge Padilla. "From fairness to welfare: Implications for the assessment of unilateral conduct under EC competition law". In European Competition Law Annual 2007: A Reformed Approach to Article 82 EC, edited by Claus-Dieter Ehlermann and Mel Marquise. Oxford: Hart Publishing, 2008.

Amato, Giuliano. Antitrust and the Bounds of Power: The Dilemma of Liberal Democracy in the History of the Market. Oxford: Hart Publishing, 1997.

Andreangeli, Arianna. "Competition law and fundamental rights". Journal of European Competition Law \& Practice 8, no. 8 (2017): 524-538.

Arena, Amedeo. "The emergence of a WTO antitrust jurisprudence through cross-fertilization from other international antitrust institutions: The case for procedural fairness as a necessary precondition". In Procedural Fairness in Competition Proceedings, edited by Paul Nihoul and Tadeusz Skonczny. Cheltenham: Edward Elgar Publishing, 2015.

Bronckers, Marco and Anne Vallery. "No longer presumed guilty? The impact of fundamental rights on certain dogmas of EU competition law". World Competition 34, no. 4 (2011): 535-570.

Buckley, Frank H. “Three theories of substantive fairness”. Hofstra Law Review 19, no. 1 (1990): 33-66.

de Boer, Nik J. "Fundamental rights and the EU internal market: Just how fundamental are the EU treaty freedoms? A normative enquiry based on John Rawls' political philosophy". Utrecht Law Review 9, no. 1 (2013): 148-168.

Edwards, C. D. Control of Cartels and Monopolies: An International Comparison. Dobbs Ferry, NY: Oceana Publications, 1967.

Flattery, Jamie. "Balancing efficiency and justice in EU competition law: Elements of procedural fairness and their impact on the right of a fair hearing". The Competition Law Review 7, no. 1 (2010): 53-81.

Forrester, Ian. "Modernization of EC competition law". Fordham International Law Journal 23, no. 4 (2000): 1028-1088.

Gentile, Giulia. "The ECJ as the EU Court of Appeal: Some evidence from the appeal caselaw on the non-contractual liability of the EU". Review of European Administrative Law 13, no. 1 (2020): 73-107. 
Gerard, Damien. "Fairness in EU competition policy: Significance and implications". Journal of European Competition Law \& Practice 9, no. 4 (2018): 211-212.

Graells, Albert Sanchez and Francisco Marcos. "Human rights' protection for corporate antitrust defendants: Are we not going overboard?". In Paul Nihoul and Tadeusz Skoczny, Procedural Fairness in Competition Proceedings. Cheltenham: Edward Elgar Publishing, 2015.

Grear, Anna. Redirecting Human Rights: Facing the Challenge of Corporate Legal Humanity. United Kingdom: Palgrave Macmillan Limited, 2010.

Harlow, Carol and Richard Rawlings. Process and Procedure in EU Administration. Bloomsbury Publishing, 2014.

Hesse,Renata."Andneverthetwainshallmeet?Connectingpopularandprofessionalvisions for antitrust enforcement”. 20 September 2016. https://www.justice.gov/opa/speech/ acting-assistant-attorney-general-renata-hesse-antitrust-division-delivers-opening.

Kalintiri, Andriani. Evidence Standards in EU Competition Enforcement. Oxford: Hart Publishing, 2019.

Kaplow, Louis and Steven Shavell. "The conflict between notions of fairness and the pareto principle". American Law and Economics Review 1, no. 1/2 (2000): 63-77.

Landini, Sara. "Private enforcement and market regulation". Market and Competition Law Review II, no. 2 (2018): 47-70.

Lianos, Ioannis. "Polycentric competition law". Current Legal Problems 71, no. 1 (2018): 161-213.

Lianos, Ioannis, Nicola Countouris and Valerio de Stefano. "Re-thinking the competition law/labour law interaction: Promoting a fairer labour market”. European Labour Law Journal 10, no. 3 (2019): 291-333.

Marco Colino, Sandra. "The antitrust F word: Fairness considerations in competition law". Social Science Research Network, 2018. https://bit.ly/2Gd65I4.

Mullan, David J. "Natural justice and fairness - Substantive as well as procedural standards for the review of administrative decision-making?". Revue de Droit de McGill 27, no. 2 (1981): 250-298.

Nazzini, Renato. The Foundations of European Union Competition Law: The Objective and Principles of Article 102. Oxford: Oxford University Press, 2011.

Oliver, Peter. "Companies and their fundamental rights: A comparative perspective". International and Comparative Law Quarterly 64, no. 3 (2015): 661-696.

O’Neill,Aidan. “Competitionlawandfundamentalrights:Someunresolvedissues”.May2011. https://www.matrixlaw.co.uk/wp-content/uploads/2016/03/18_05_2011_02_37_13_ Aidan-ONeill-QC-COMPETITION-LAW-AND-FUNDAMENTAL-RIGHTS.pdf.

Peres, Catarina Vieira. "Developments in the case law of the EU Courts in competition law in 2016". Market and Competition Law Review I, no. 1 (2017): 187-221. 
Rawls, John. A Theory of Justice. Harvard: Harvard College Press, 2005.

Sokol, D. Daniel and Andrew T Guzman. Antitrust Procedural Fairness. Oxford: Oxford University Press, 2019.

Sokol, D. Daniel. "The new procedural fairness in competition law: Global developments". Journal of European Competition Law \& Practice 10, no. 4 (2019): 197-198.

Stones, Ryan. "Commitment decisions in EU competition enforcement: Policy effectiveness v. the formal rule of law". Yearbook of European Law 38 (2019): 361-399.

Sunstein, Cass R. "Two conceptions of procedural fairness". Social Research: An International Quarterly 73, no. 2 (2006): 619-646.

Tyler, Tom R. "Procedural justice, legitimacy, and the effective rule of law". Crime and Justice 30 (2003): 283-357.

Ullrich, Hanns. The Evolution of European Competition Law: Whose Regulation, Which Competition? United Kingdom: Edward Elgar Publishing, 2006.

Van Cleynenbreugel, Pieter. "Effectiveness through fairness? 'Due process' as an institutional precondition for effective decentralized EU competition law enforcement". $9^{\text {th }}$ ASCOLA Conference Warsaw 2014 on Procedural Fairness in Competition Proceedings. 2014. http://www.ascola-conference-2014.wz.uw.edu.pl/conference_ papers/VanCleynenbreugel.pdf.

Zimmer, Daniel. The Goals of Competition Law. United Kingdom: Edward Elgar Publishing, 2012. 